\title{
THE IMPORTANCE OF THE BUSKO-ZDRÓJ AND SOLEC-ZDRÓJ SPAS FOR TOURIST ACCOMMODATION IN ŚWIĘTOKRZYSKIE VOIVODESHIP
}

\author{
TADEUSZ CIUPA, ${ }^{1}$ ROMAN SULIGOWSKI ${ }^{2}$ \\ Jan Kochanowski University in Kielce \\ Faculty of Mathematics and Natural Sciences, Institute of Geography \\ ${ }^{1}$ e-mail: tciupa@ujk.edu.pl \\ 2 e-mail: rsulig@ujk.edu.pl
}

JEL CODES

KEYWORDS

ABSTRACT
R10, Z30, Z32

spa towns, Busko county, state of tourist development indices, tourist traffic intensity indices

The presented paper shows the results of a comparative analysis describing the state and occupancy rate of accommodation establishments in Busko county in 2000 and 2015, including the influence of Busko-Zdrój and Solec-Zdrój where two major spas are located. With the use of the data from the Central Statistical Office describing establishments that provide accommodation services, a number of indices characterizing tourist management (i.a. density of the accommodation establishments, Charvat's, Baretje's and Defert's indices) and tourist traffic (Schneider's and Defert's) were calculated. The analysis of the indices values obtained has shown that Busko county can be classified as well-developed touristically in comparison to other counties in the voivodeship, and even in Poland. It has been proved that the two dynamically functioning spas contribute significantly to such an assessment.

\section{Introduction}

In recent years, it is noticeable that spas are developing intensively and that their role on the market of tourist services is increasing (Góra, 2013; Panasiuk, 2013; Wójcikowski, 2013). The research carried out by Kapczyński and Szromek (2008), based on the Butler's model (1980), has shown that two life cycles can be identified in the development of Polish spas in the period 19492006. The authors prove that since 2000, a new development stage of modern spas has started. 
This tendency is reflected in the greater interest of both domestic and foreign tourists in the Polish spas' offers (Kraś, 2011). The mentioned changes often result in the increase of the spas' attractiveness, mainly due to the development and improvement of existing infrastructure - including the accommodation establishments. Busko-Zdrój can be considered one of the most important and well known spas in Poland (Gonda-Soroczyńska, 2012; Górka, Wartecka-Ważyńska, 2013). Its dynamic growth at the beginning of the $21^{\text {st }}$ century is most probably related to the discovery (2006) of the new and rich underground sulfur water deposits - Las Winiarski and Busko-Północ. In 2008, the construction of a hydrotechnical complex began and curative waters started to be exploited and delivered to 10 spa resorts. These waters are now widely used in bathing, drinking and inhalation therapies (Lisik, 2010; Lisik, Szczepański, 2014). Another spa in Busko county that also uses sulfur waters is Solec-Zdrój (Łajczak, 2001; Gonda-Soroczyńska, 2011). This raises a question: how important are the Busko-Zdrój and Solec-Zdrój spas for shaping the tourist accommodation in the Busko county compared to the Świętokrzyskie Voivodeship in the early $21^{\text {st }}$ century?

The aim of the present paper is to determine the importance of the Busko-Zdrój and SolecZdrój spas for the development of the tourist accommodation and its use in Busko county in the years 2000 and 2015 in comparison to the other counties in the Świętokrzyskie Voivodeship.

Busko county is one of the 14 administrative units of this rank in the voivodeship (13 counties and 1 city with county rights) (Figure 1).

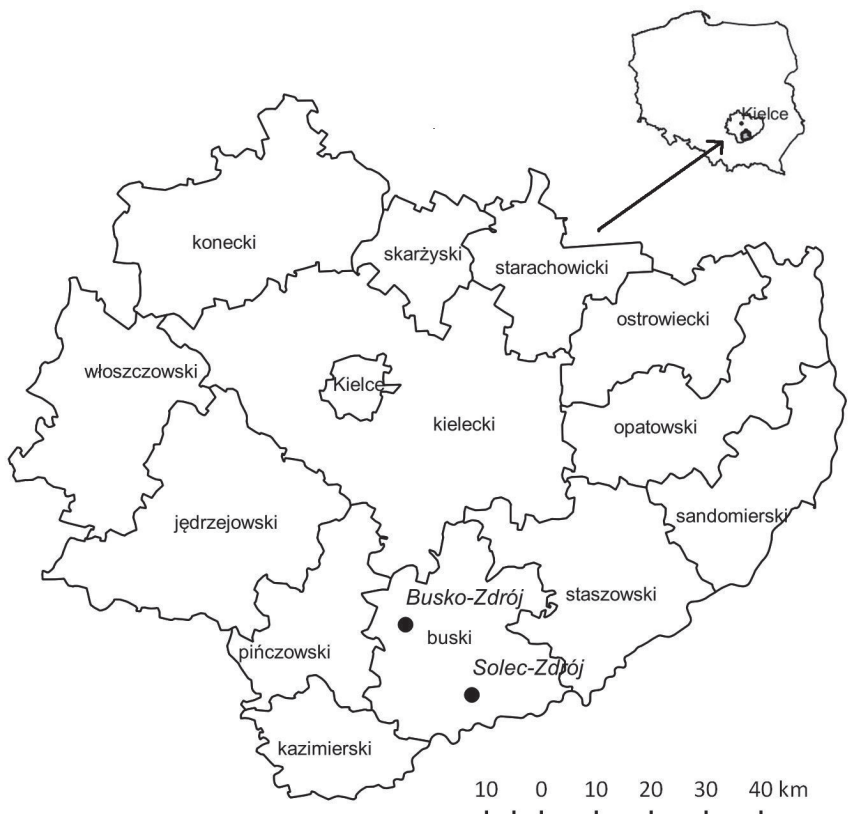

Figulpe 1. Location of Busko-Zdrój Spa and Solec-Zdrój Spa in Busko county in the perspective of Świętokrzyskie Voivodeship

Source: own elaboration. 
Busko county with the area of $968 \mathrm{~km}^{2}$ was inhabited by 73.4 thousand people in 2015, which in comparison to the whole Świętokrzyskie Voivodeship equaled to $8.3 \%$ and $5.8 \%$ respectively. Almost 17,000 people live in Busko-Zdrój which is a city with the county rights, while Solec-Zdrój is the seat of the rural municipality with 5,000 inhabitants.

\section{Methods}

To evaluate the tourist function of selected administrative units, a number of commonly used indices were applied (Chudy-Hyski, 2006; Kurek, Mika, 2008; Lijewski, Mikułowski, Wyrzykowski, 2008; Szromek, 2012). A relative character of the used indices allows to compare and assess administrative units of different size and demographic potential. The indices were grouped in two different types characterizing:

1. State of tourist development:

- accommodation density - number of accommodation facilities by administrative area per: a) $100 \mathrm{~km}^{2}$ and b) 1,000 permanent inhabitants (author's own index),

- tourist saturation index (Charvat's index) - number of accommodation facilities per $1 \mathrm{~km}^{2}$,

- tourist function of the area (Baretje's and Defert's index) - number of bed places per 100 permanent inhabitants.

2. Tourist traffic intensity:

- Schneider's index - number of tourists accommodated per 1,000 permanent inhabitants,

- Defert's index - number of tourists accommodated per $1 \mathrm{~km}^{2}$.

GIS techniques were used to compile the cartograms showing the average period of tourist stay in accommodation establishments and the accommodation occupancy rate in the counties of the Świętokrzyskie Voivodeship in the years 2000 and 2015. The spatial diversity of these indices was presented in five class intervals.

The analysis was based on the Statistical Office data published in Kultura i turystyka w województwie świętokrzyskim (2001) and on the Bank Danych Lokalnych (Local Data Bank) website (2016) which consisted of statistics on accommodation establishments existing in Świętokrzyskie Voivodeship in 2000 and 2015. The data included 11 types of tourist accommodation existing in the voivodeship: hotels, motels, boarding houses, other hotel facilities, youth shelters, holiday centres, health establishments, agrotourism lodgings, complexes of tourist cottages, rooms for rent and other not classified facilities (Table 1). These statistics do not include all the existing accommodation establishments, especially services offered by private guest rooms and 42 agrotourism farms in the area of Busko county.

\section{Resulls}

The tourist accommodation establishments in Busko county in the year 2000 consisted of 11 objects, which was 7\% compared to 162 establishments in the whole Świętokrzyskie Voivodeship (Table 1). By 2015, there were already 32 accommodation establishments in the county, which 
constituted 13\% of all such establishments in the voivodeship. In Busko-Zdrój Spa and Solec-Zdrój Spa there were 29 establishments, including 8 health establishments ( 6 and 2 respectively), 7 hotels (5 and 2) and 4 boarding houses ( 2 and 2).

Accommodation density per $100 \mathrm{~km}^{2}$ in Busko county increased in the analyzed 15 -year period (2000-2015) from 1.14 to 3.31, while in the whole voivodeship - from 1.39 to 2.10. This situated the county on the third rating in the voivodeship (after Kielce city and Kielce county) (Figure 2). The value of the analyzed index was slightly higher than its average value in Poland (3.21 accommodation object per $100 \mathrm{~km}^{2}$ ).

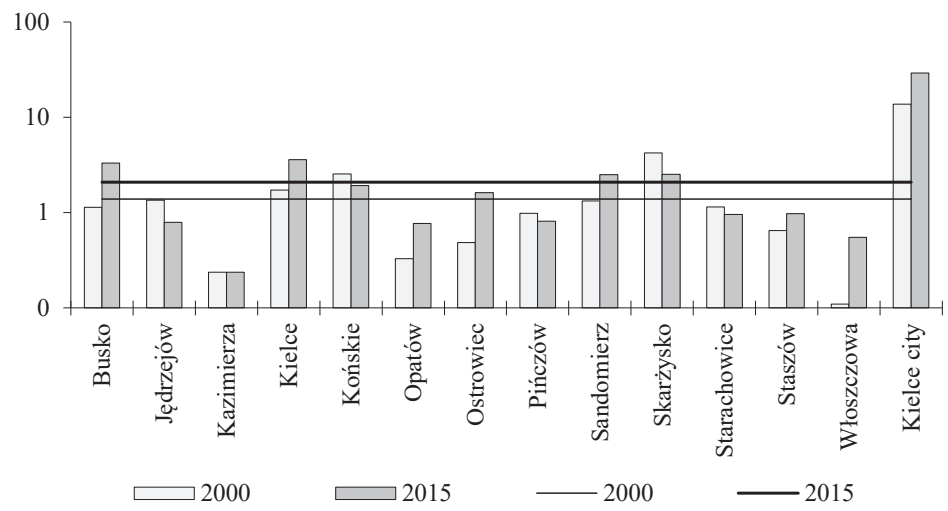

Figure 2. The tourist accommodation density index (number of facilities per $100 \mathrm{~km}^{2}$ ) in the counties of Świętokrzyskie Voivodeship in 2000 and 2015 (the horizontal line indicates the average value in the voivodeship) Source: own elaboration.

The number of accommodation establishments per an administrative area per 1,000 permanent inhabitants is another synthetic index that allows to characterize tourist accommodation. In the year 2000 in Świętokrzyskie Voivodeship its value was only 0.12 (Figure 3), while in 2015 it reached 0.19 (average in Poland - 0.26). In 2015, Busko county with 0.44 establishments per 1,000 permanent inhabitants was the first among other counties in the voivodeship, whereas in 2000 it occupied fifth position (0.14).

The tourist accommodation establishments in Busko county in 2000 consisted of 318 bed places $\left(9^{\text {th }}\right.$ place in the Świętokrzyskie Voivodeship) and their numbers have been increasing until 2015, when the number of bed places reached 3,086 ( $2^{\text {nd }}$ place after kielecki county). These resources are located in two spas: Busko-Zdrój and Solec-Zdrój, which host $97 \%$ of all beds available for tourists in the county, $49.9 \%$ of which being located in health establishments (Table 1). The number of bed places offered in hotels located in the county in 2015 amounted to 1149, from which 632 in BuskoZdrój (5 hotels) and 417 in Solec-Zdrój (2 hotels). In comparison to 2000, the number of bed places available in the county has increased forty times. 


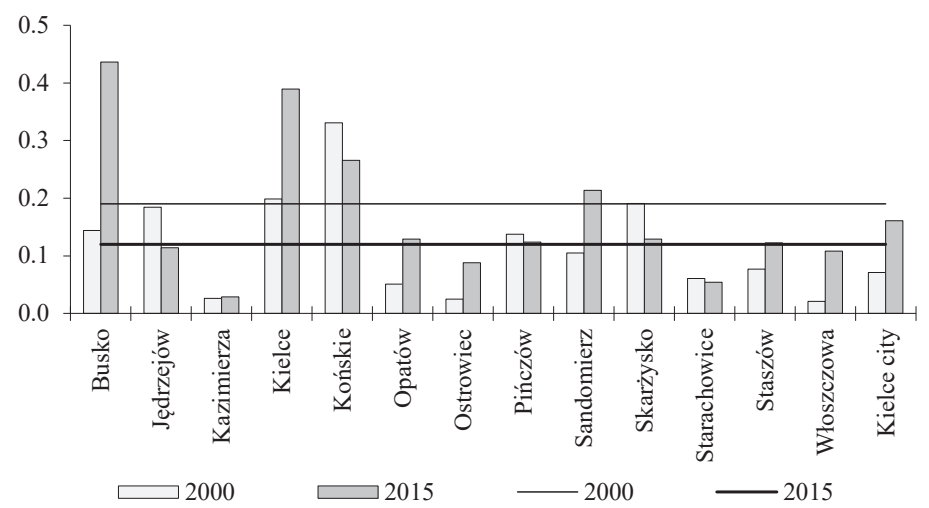

Figure 3. The tourist accommodation density index (number of facilities per 1,000 permanent inhabitants) in the counties of Świętokrzyskie Voivodeship in 2000 and 2015 (the horizontal line indicates the average value in the voivodeship)

Source: own elaboration.

Table 1. Types of accommodation establishments and bed places in Busko county compared to Świętokrzyskie Voivodeship

\begin{tabular}{|c|c|c|c|c|c|c|c|c|}
\hline \multirow{3}{*}{ Establishment type } & \multicolumn{6}{|c|}{ Bed places } & \multicolumn{2}{|c|}{$\begin{array}{l}\text { Share of Busko county } \\
\text { in the voivodeship }\end{array}$} \\
\hline & \multicolumn{3}{|c|}{2000} & \multicolumn{3}{|c|}{2015} & 2000 & 2015 \\
\hline & Busko & Solec & county & Busko & Solec & county & \multicolumn{2}{|c|}{$\%$} \\
\hline Hotels & 28 & - & 28 & 632 & 417 & 1,149 & 2.3 & 15.5 \\
\hline Motels & 26 & - & 50 & - & - & - & 14.7 & - \\
\hline Boarding houses & 111 & 30 & 141 & 67 & 82 & 149 & 28.5 & 30.8 \\
\hline Other hotel facilities & - & - & - & 19 & 47 & 66 & - & 19.8 \\
\hline Youth shelters & - & - & 38 & - & - & - & 5.7 & - \\
\hline Holiday centres & 20 & & 20 & - & 60 & 60 & 1.5 & 6.7 \\
\hline Health establishments ${ }^{*}$ & - & - & - & 1,351 & 189 & 1,540 & - & 100.0 \\
\hline Agrotourism lodgings & - & - & - & - & 10 & 17 & - & 2.9 \\
\hline Complexes of tourist cottages & - & - & - & - & 10 & 10 & - & 1.6 \\
\hline Rooms for rent & - & - & - & 55 & - & 55 & - & 20.5 \\
\hline Other & 20 & 7 & 41 & 40 & - & 40 & 3.0 & 3.5 \\
\hline Total & & 318 & & & 3,086 & & 3.2 & 19.2 \\
\hline
\end{tabular}

* According to the Act on Health Resorts, Health Resort Areas, Health Resort Medical Care and Health Resort Communes from 28 July 2005 (Journal of Laws from 2012 item 651, as amended).

Source: Kultura i Turystyka... (2001), Bank Danych Lokalnych (2016); own elaboration.

In the opinion of Wójcikowski (2013), Busko-Zdrój belongs to a relatively small group of spa towns in Poland characterized by a very diversified offer of accommodation standards (Table 1). The dynamic increase in the total number of the available beds that was observed is a result of intensive development of spa infrastructure at the beginning of the $21^{\text {st }}$ century. In the case of 
Busko-Zdrój, the most important factor leading to the previously mentioned development was the discovery (in 2006) and exploitation (since 2009) of two underground sulfur water deposits (Las Winiarski and Busko-Północ), meant to be used for therapeutic baths.

In 2000 Busko county had an average of 29 bed places per one accommodation establishment, and in 2015 already 96. In this respect the county ranked first in the voivodeship with an average of 56 bed places per facility, the average in Poland being 71 bed places.

The obtained values of the tourist saturation index (Charvat's index) show that in 2000 Busko county was still poorly equipped with accommodation establishments. The average number of bed places was only 0.33 per $1 \mathrm{~km}^{2}$. However, the indices value grew to reach 3.19 in 2015 , exceeding the average for the voivodeship (1.17) over 2.5 times (Figure 4).

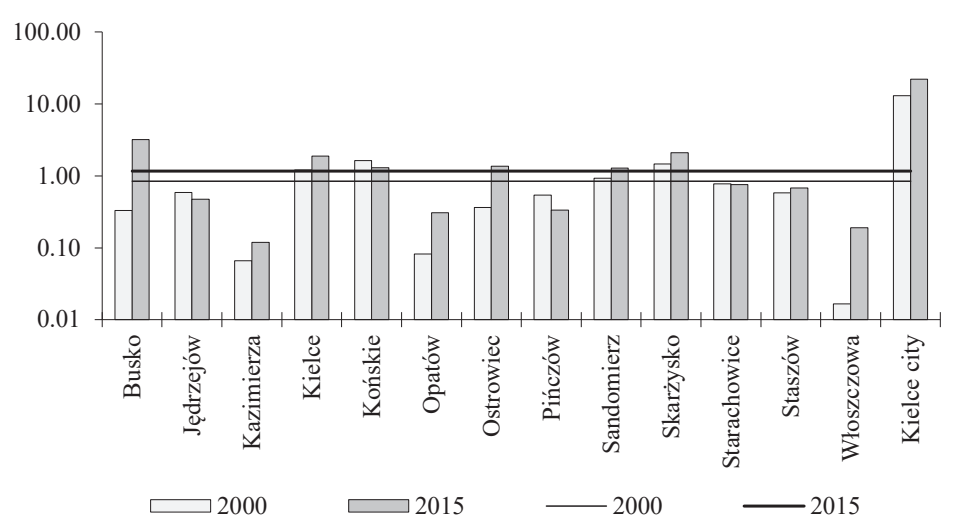

Figure 4. Tourist saturation index - Charvat's index (bed places per $1 \mathrm{~km}^{2}$ ) in the counties of Świętokrzyskie Voivodeship in 2000 and 2015 (the horizontal line indicates the average value in the voivodeship)

Source: own elaboration.

Busko county has become the best equipped county in terms of accommodation establishments among other local government units of the same rank. It is worth noting that the value of this index for Busko-Zdrój (180 bed places per $1 \mathrm{~km}^{2}$ ) exceeds the threshold value set by Warszyńska (1985) at the level of 50 bed places as a characteristic for the municipalities which are well-developed touristically. Charvat's index value determined by Pytel (2010) for spas in Silesian Voivodeship is half as high as for Busko-Zdrój.

The values of the tourist function index (Baretje's and Defert's) in the analyzed counties are strongly differentiated and picture Busko county as very favorable for tourism development (Figure 5). In 2000, this county was located halfway on the scale with a value of 0.42 beds per 100 inhabitants, with an average for Świętokrzyskie Voivodeship of 0.75 . However, in 2015 this index reached its highest value in Busko county (4.2), exceeding the value calculated for the county that followed (Kielce city) almost twice, and four times - the average in the voivodeship (1.08). On the national scale, however, it was lower than the values in other counties with spas, for example 
Aleksandrów county with the Ciechocinek Spa - 9.8 bed places per 100 inhabitants. In Busko-Zdrój city itself, the value of this index reaches 13 beds per 100 inhabitants, and in the Solec-Zdrój municipality exceeds 17 .

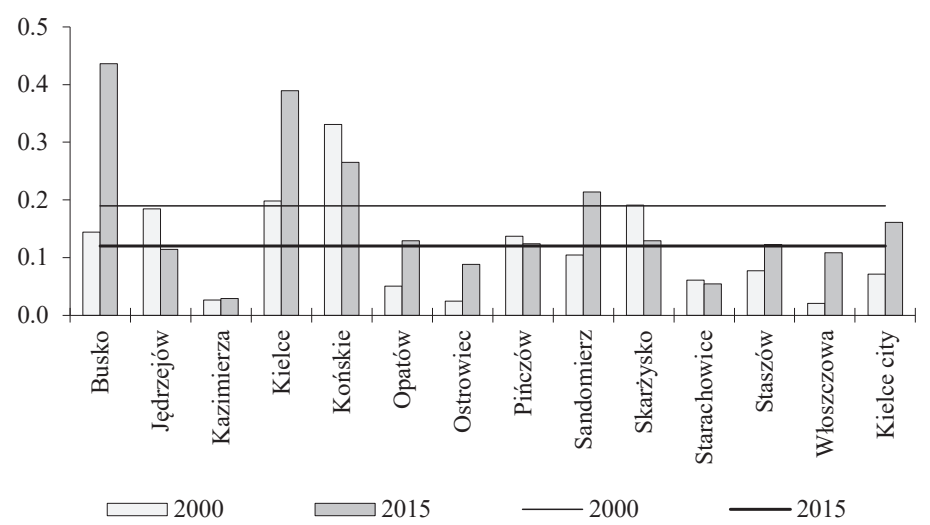

Figure 5. Tourist function of the area - Baretje's and Defert's index (bed places per 1,000 permanent inhabitants) in the counties of Świętokrzyskie Voivodeship in 2000 and 2015 (the horizontal line indicates the average value in the voivodeship)

Source: own elaboration.

The tourist traffic intensity index is based on the number of tourists using accommodation services. In 2000 in Busko county, almost 10.6 thousand people used those services and in 2015 - almost 90 thousand, which means an increase by 8.5 times, whereas in the whole voivodeship in that period an increase by only 2 times was observed. It is worth noting that in this county the number of foreign visitors has increased from 159 (2000) to 1453 (2015). In 2015, tourists from the member states of the European Union accounted for about $65 \%$ of the total number of foreign guests, dominated by the Germans (300) and the British (132). This can be seen as one of the effects of Poland's participation in the EU structures since 2004. In 2015, 1164 foreign tourists used the Busko-Zdrój accommodation establishments (80\% of the total number of tourists in the county), while in Solec-Zdrój - 179 (12\%).

Schneider's tourist traffic intensity index shows the dominance of Busko county among other units of the same rank in Świętokrzyskie Voivodeship (Figure 6). In 2015 it reached a value of 1,223 tourists using accommodation per 1,000 permanent inhabitants and was 3.5 times higher than the average in the voivodeship (410 tourists), and almost twice as high as the value obtained for Kielce city. Taking into account, however, the population of the city of Busko-Zdrój itself, the index reached 3,336 in 2015. According to Warszyńska (1985), a well-developed tourist area is considered to be a unit for which indices value exceeds 500 tourists per 1,000 inhabitants. It is worth noting that in Świętokrzyskie Voivodeship in 2015, only 2 units (Kielce city and Sandomierz county) exceeded this threshold, apart from Busko county. In the analyzed period, in Busko county, there was 
one of the highest growth rates of this index in the voivodeship reaching $881 \%$ (Figure 6), which is a result of the dynamic development of the two spas.

Busko county also occupies a high position in the ranking of tourism intensity determined by Defert's index (Figure 6). The analysis of the diagram shows that the number of tourists in tourist accommodation establishments per $1 \mathrm{~km}^{2}$ in 2015 was the highest in the city of Kielce $(1,225)$, followed by Busko county (93). Three counties - Sandomierz, Skarżysko and Kielce - were above the average of 44 tourists using accommodation per $1 \mathrm{~km}^{2}$. Applying the analysis only to the area of Busko-Zdrój would make the value of the index exceed 4,500 persons per $1 \mathrm{~km}^{2}$, which means that the unit is well above 1,000, the value proposed by Warszyńska (1985) as a threshold for classifying the area as well-developed touristically. For comparison, the value of Defert's index for the Ustron Spa was 2,655 persons per $1 \mathrm{~km}^{2}$ in 2012 (Hendel, 2016).

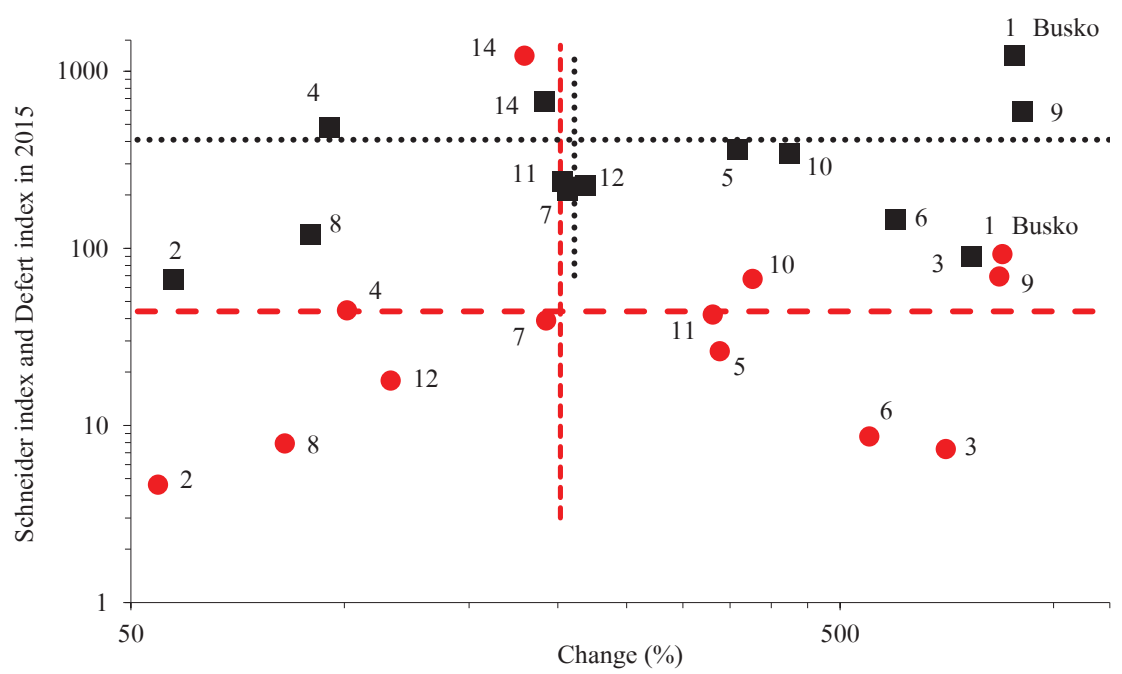

Figure 6. Tourist traffic intensity - Schneider's index (tourists in tourist accommodation per 1,000 permanent inhabitants) and Defert's index (tourists in tourist accommodation per $1 \mathrm{~km}^{2}$ ) in 2015 and their changes in 2000-2015 period in the counties of Świętokrzyskie Voivodeship. Horizontal lines show the average values of the indices for the voivodeship (dotted line - Schneider's, interrupted - Defert's indices). County: 1 - Busko, 2 - Jędrzejów, 3 - Kazimierza, 4 - Kielce, 5 - Końskie, 6 - Opatów, 7 - Ostrowiec, 8 - Pińczów, 9 - Sandomierz, 10 - Skarżysko, 11 - Starachowice, 12 - Staszów, 13 - Włoszczowa, 14 - Kielce city

Source: own elaboration.

The accommodation establishments of Busko county were used by tourists in average for 7.8 days in 2015, while in 2000 only for 3.7 (Figure 7). It was the highest increase of tourist stay period in the analyzed administrative units, which was a result of the increase in the demand for rehabilitation services in the health establishments of Busko-Zdrój and Solec-Zdrój. A small increase of this index value was recorded only in three other counties (Kazimierza, Kielce, and Ostrowiec) and in the entire voivodeship treated as one unit (increase of $8 \%$, from 2.6 to 2.8 days). In Poland, an 
average period of tourist stay in accommodation establishments amounted to 2.6 days in 2015 and was close to the value calculated for 2000, whereas in terms of the occupancy of accommodation establishments, a satisfactory situation expressed by $43.9 \%$ was already observed in Busko county as early as in 2000 (Figure 8). At that time, the county's accommodation base was second best in the voivodeship (after Kielce - 48.9\%). Over the last 15 years, the index of the accommodation occupancy was also rising most dynamically in Busko county to reach $66.3 \%$ in 2015. This situation
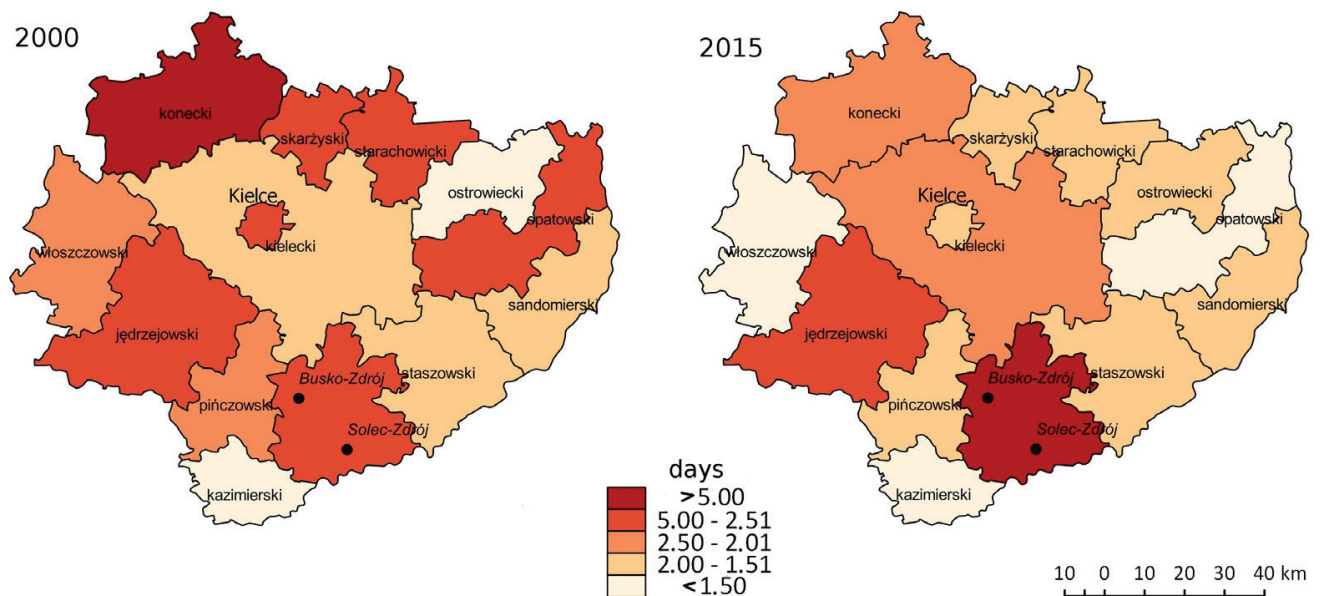

Figure 7. Average period of tourist stay in accommodation establishments in the counties of Świętokrzyskie Voivodeship in 2000 and 2015

Source: own elaboration.
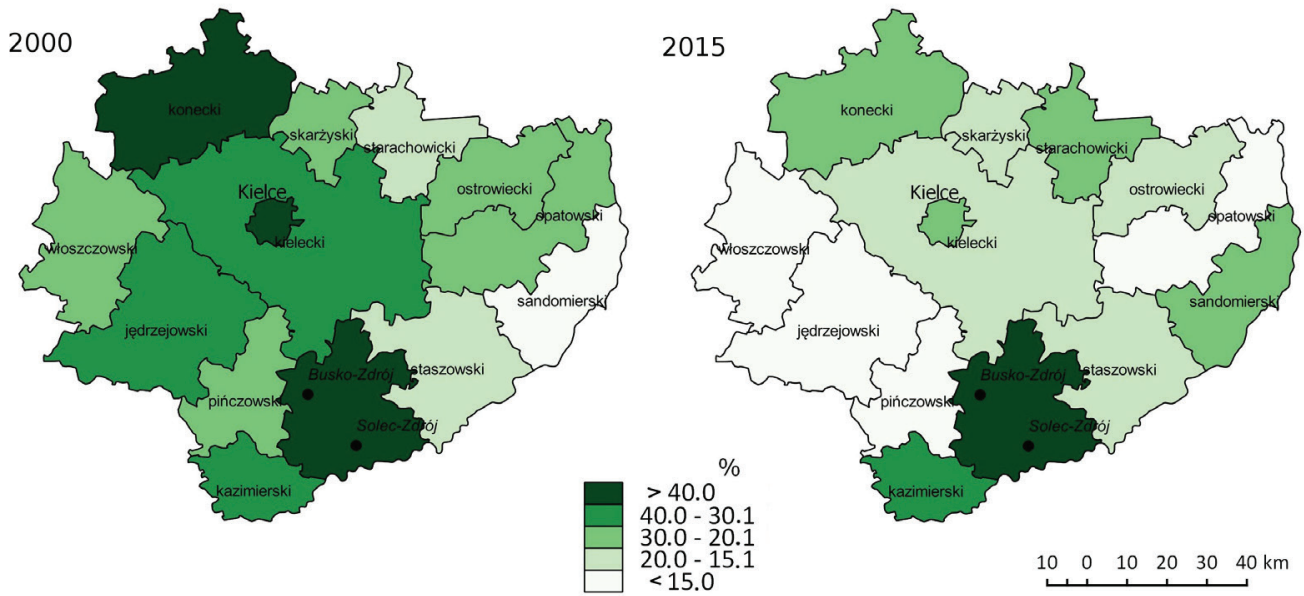

Figure 8. Accommodation occupancy rate in the counties of Świętokrzyskie Voivodeship in 2000 and 2015

Source: own elaboration. 
was not accidental, as the occupancy of accommodation in all Polish spas has been high in recent years. This is due to the fact that spas used for healing purposes were classified as accommodation establishments in accordance with the Act on Health Resorts (2005).

According to the law, the duration of stay in such establishments, depending on the form of treatment, lasts at least 21 days. At the same time, it is worth noting that there has also been an increase in interest in full-paid, short-term stays in those spas, including weekend stays - using spare accommodation resources. In the voivodeship, a positive tendency in accommodation use in the period 2000-2015 was documented only in Sandomierz and Starachowice counties. The average occupancy accommodation rate in the whole Świętokrzyskie Voivodeship decreased from 33.1\% to $29.8 \%$ at that time.

\section{Conclusions}

The presented multidirectional, quantitative analysis of Busko county tourist accommodation, among which there are two well-known spas - Busko-Zdrój and Solec-Zdrój, indicates its dynamic development since the beginning of the $21^{\text {st }}$ century. This process has been documented using objective measures for tourist development and tourist traffic intensity which allowed for carrying out a comparative analysis of Busko county accommodation establishments in 2000 and in 2015 regarding other administrative units of this rank in Świętokrzyskie Voivodeship.

In 2015, Busko county was distinctive because of the number of its accommodation establishments per 1,000 inhabitants ( 0.44 compared to the average in the voivodeship - 0.19). Over the 15 years there was an increase in the number of bed places offered from 318 (2000) to 3,086 (2015), with $97 \%$ of all bed places available in the county situated in two spas. It is worth noting that nearly $50 \%$ were located in health establishments. At that time, the largest increase in accommodation in Busko county (40 times) concerned hotels.

The very favorable tourist function of Busko county was confirmed by the results of the commonly used Baretje's and Defert's index. In 2015, in Busko county it reached the highest value among all districts of the voivodship ( 4.2 beds per 100 inhabitants), surpassing the average of the voivodship (1.08) almost four times. In terms of tourist traffic intensity defined by Schneider's index, Busko county occupied the dominant position in the voivodeship (410 tourists using accommodation per 1,000 permanent inhabitants in 2000 and 1,223 in 2015). For the city of Busko-Zdrój, this index reached the value of 3,336 in 2015.

Busko county, in comparison to the other counties in the voivodeship, stood out with the longest period of tourist stay (7.8 days in 2015), which was a result of the provision of services in spas (the average length of stay in accommodation establishments for Poland - 2.6 days).

The accommodation occupancy rate was very remarkable in Busko county as it increased from 43.9 to $66.3 \%$ in the 15 -year period, while in Świętokrzyskie Voivodship it decreased from 33.1 to $29.8 \%$.

The analysis of the obtained indicators shows that the Busko country can be classified as touristically well-developed due to two dynamically functioning modern spas - Busko-Zdrój and 
Solec-Zdrój. This was possible thanks to the discovery of new healing sulfur water resources at the beginning of the $21^{\text {st }}$ century, which led to rapid development of the two aforementioned spas.

The dynamic development of the two spas and the accompanying tourist accommodation facilities in the Busko country has been confirmed as they have been admitted to the innovative spa and tourist cluster named Health and Tourism 'Spas - Pearls of Eastern Poland'. Since 2013, they have also been operating within the cluster of Świętokrzyskie Spas, maintaining its headquarters in Busko-Zdrój. These clusters aim at improving the quality of the economic and social life, and at creating new innovative tourism products including sulfur healing waters.

\section{References}

Bank Danych Lokalnych (Local Data Bank) (2016). Warszawa: Główny Urząd Statystyczny.

Butler, R.W. (1980). The concept of tourism area cycle of evolution: Implications for management of resources. Canadian Geographer, 1 (24), 5-12.

Chudy-Hyski, D. (2006). Ocena wybranych uwarunkowań rozwoju funkcji turystycznej obszaru. Infrastruktura i Ekologia Terenów Wiejskich, 2/1, 129-141.

Ciupa, T., Biernat., T. (2007). Obiekty noclegowe i ich wykorzystanie w województwie świętokrzyskim na tle bazy noclegowej Polski. Zeszyty Naukowe Uniwersytetu Szczecińskiego, 466, Ekonomiczne Problemy Turystyki, 9, $37-45$.

Gonda-Soroczyńska, E. (2011). Przestrzeń uzdrowiskowa w krajobrazie kulturowym wsi na przykładzie uzdrowiska Solec-Zdrój. Infrastruktura i Ekologia Terenów Wiejskich, 1, 39-49.

Gonda-Soroczyńska, E. (2012). Funkcja uzdrowiskowa małego miasta na przykładzie Buska-Zdroju. Infrastruktura i Ekologia Terenów Wiejskich, 2, 5-16.

Góra, J. (2013). Miejska turystyka uzdrowiskowa i kierunki jej ewolucji w Polsce. Studia Ekonomiczne. Zeszyty Naukowe Uniwersytetu Ekonomicznego w Katowicach, 147, 53-67.

Górka, J., Wartecka-Ważyńska, A. (2013). Stan obecny i możliwości rozwoju turystyki uzdrowiskowej w Polsce. Zeszyty Naukowe Uniwersytetu Szczecińskiego, 784, Ekonomiczne Problemy Turystyki, 3 (23), 193-207.

Hendel, M. (2016). Przydatność wskaźników funkcji turystycznej w ocenie rozwoju turystycznego obszaru na przykładzie gminy Ustroń. Zeszyty Naukowe Politechniki Śląskiej, Organizacja i Zarządzanie, 87, 157-170.

https://bdl.stat.gov.pl/BDL (20.02.2017).

Kapczyński, A., Szromek, A.R. (2008). Hypotheses concerning the development of Polish spas in the years 1949-2006. Tourism Management, 29, 1035-1037.

Kraś, J. (2011). Istota i znaczenie turystyki uzdrowiskowej w Polsce. Seminare, 29, 151-162.

Kultura i turystyka w województwie świętokrzyskim (2001). Kielce: Urząd Statystyczny.

Kurek, W., Mika, M. (2008). Turystyka jako przedmiot badań naukowych. In: W. Kurek (ed.), Turystyka (pp. 11-49). Warszawa: Wydawnictwo Naukowe PWN.

Lijewski, T., Mikułowski, B., Wyrzykowski, J. (2008). Geografia turystyki Polski. Warszawa: PWE.

Lisik, R. (2010). Złoża leczniczych wód siarczkowych Las Winiarski i Busko-Północ. In: R. Lisik (ed.), Wody siarczkowe w rejonie Buska-Zdroju (pp. 267-274). Kielce: XYZ.

Lisik, R., Szczepański, A. (2014). Siarczkowe wody lecznicze w części zapadliska przedkarpackiego. Kielce: Fundacja Posteris.

Łajczak, A. (2001). Źródła mineralne Niecki Nidziańskiej. Czasopismo Geograficzne, 2 (72), 151-184.

Panasiuk, A. (2013). Miejsce turystyki uzdrowiskowej w strukturze rynku turystycznego. Zeszyty Naukowe Uniwersytetu Szczecińskiego, 784, Ekonomiczne Problemy Turystyki, 3 (23), 9-22.

Pytel, S. (2010). Rola turystyki kulturowej w rozwoju gmin województwa śląskiego. Prace Komisji Krajobrazu Kulturowego, 14, 273-282. 
Szromek, A.R. (2012). Wskaźniki funkcji turystycznej. Koncepcja wskaźnika funkcji turystycznej i uzdrowiskowej. Gliwice: Wydawnictwo Politechniki Śląskiej.

Ustawa z dnia 28.07.2005 r. o lecznictwie uzdrowiskowym, uzdrowiskach i obszarach ochrony uzdrowiskowej oraz o gminach uzdrowiskowych, Dz.U. 2005.167.1399.

Warszyńska, J. (1985). Funkcja turystyczna Karpat polskich. Folia Geographica. Series Geographica-Oeconomica, 18, $1-88$.

Wójcikowski, W. (2013). Przestrzeń publiczna i usługowa miasta o funkcji uzdrowiskowej. Acta Universitatis Lodziensis, Folia Geographica Socio-Oeconomica, 15, 209-224.

\section{ZNACZENIE UZDROWISK BUSKO-ZDRÓJ I SOLEC-ZDRÓJ W KSZTAŁTOWANIU BAZY NOCLEGOWEJ W WOJEWÓDZTWIE ŚWIĘTOKRZYSKIM}

SŁOWA KLUCZOWE

STRESZCZENIE uzdrowiska, powiat buski, wskaźniki stanu zagospodarowania turystycznego, wskaźniki intensywności ruchu turystycznego

W pracy przedstawiono analizę porównawczą stanu i wykorzystania bazy noclegowej powiatu buskiego w 2000 i w 2015 roku z uwzględnieniem wpływu dwóch uzdrowisk tj. Busko-Zdrój i Solec-Zdrój. Korzystając z danych Urzędu Statystycznego dotyczących obiektów świadczących usługi noclegowe obliczono wskaźniki charakteryzujące stan zagospodarowania turystycznego (m.in. gęstość obiektów noclegowych, Charvata, Baretje’a i Deferta) i intensywność ruchu turystycznego (Schneidera, Deferta). Przeprowadzona analiza wielkości uzyskanych mierników wskazuje, że powiat buski można zaliczyć do obszarów dobrze rozwiniętych pod względem turystycznym na tle jednostek tej samej rangi w województwie świętokrzyskim, a nawet niektórych w Polsce. Wykazano, że decydujący wpływ na taką ocenę wywierają dwa dynamicznie funkcjonujące tu uzdrowiska.

Translated by Paulina Toporek 